\title{
PERBANDINGAN PENINGKATAN KEKUATAN OTOT PASIEN HEMIPARESE MELALUI LATIHAN RANGE OF MOTION UNILATERAL DAN BILATERAL
}

\author{
Yanti Cahyati $^{1,2 *}$, Elly Nurachmah ${ }^{3}$, Sutanto Priyo Hastono ${ }^{4}$ \\ 1. Poltekkes Kemenkes Tasikmalaya, Jurusan Keperawatan, Tasikmalaya 46115, Indonesia \\ 2. Program Studi Magister, Fakultas Ilmu Keperawatan, Universitas Indonesia, Depok 16424, Indonesia \\ 3. Fakultas Ilmu Keperawatan, Universitas Indonesia, Depok 16424, Indonesia \\ 4. Fakultas Kesehatan Masyarakat, Universitas Indonesia, Depok 16424, Indonesia \\ *E-mail: yanti_naufal@yahoo.co.id
}

\begin{abstract}
Abstrak
Hemiparese pada klien stroke dapat menyebabkan klien mengalami berbagai kecacatan. Latihan range of motion (ROM) merupakan salah satu bentuk latihan yang dinilai efektif untuk mencegah terjadinya kecacatan. Latihan ROM bisa dilakukan dengan pendekatan bilateral yang dapat memberikan efek yang lebih baik dibandingkan dengan unilateral training. Penelitian bertujuan mengidentifikasi perbandingan latihan ROM unilateral dan bilateral terhadap kekuatan otot pasien hemiparese akibat stroke iskemik. Penelitian menggunakan desain Quasi experiment pre dan post test design. Jumlah sampel 30 responden yang terdiri dari kelompok intervensi I dan intervensi II. Evaluasi penelitian dilakukan pada hari pertama dan ketujuh. Teknik pengambilan sampel consecutive sampling. Hasil penelitian menunjukkan kekuatan otot meningkat pada kedua kelompok intervensi dan terdapat perbedaan yang signifikan antara kedua kelompok intervensi $(p=0,018, \alpha=0,05)$. Penelitian lebih lanjut tentang pengaruh penggunaan latihan ini secara terprogram dalam menangani pasien stroke dengan hemiparese perlu dilakukan.
\end{abstract}

Kata kunci: bilateral, hemiparese, kekuatan otot, latihan, ROM, stroke, unilateral

\begin{abstract}
Comparison of Hemiparesis Patient's Muscle Strength Improvement through Unilateral and Bilateral ROM Exercise. Hemiparesis on stroke client's can cause such of disability. ROM exercise is effective to prevent disability. ROM exercises can be provided with bilateral approach which gives better effect than unilateral training. This study aimed to identify the comparison between unilateral and bilateral ROM exercise on hemiparesis patient's muscle. This study used Quasi Experiment pre and post test research designs. Number of sample was 30 respondents who were divided into intervention group I and group II. Evaluation research was undertaken in the first day and seventh day. Sampling technique used was a consecutive sampling. Study results showed an there were significant differences between the two intervention groups ( $p=0018, \alpha=0,05)$. This result revealed that bilateral ROM exercises will increase muscle strength compare to unilateral ROM exercises. This study recommended the need for further research and the use of these exercises programmed in dealing with stroke patients with hemiparesis.
\end{abstract}

Keywords: bilateral, hemiparesis, muscle strength, stroke, unilateral

\section{Pendahuluan}

Stroke merupakan suatu kondisi yang digunakan untuk menjelaskan perubahan neurologik yang disebabkan oleh gangguan dalam sirkulasi darah ke bagian otak. Menurut American Heart Association (2010), stroke menyumbang sekitar satu dari setiap 18 kematian di Amerika Serikat pada tahun 2006.
Di Indonesia, stroke merupakan penyebab kematian utama pada semua umur $(15,4 \%)$. Diperkirakan 500.000 penduduk terkena stroke setiap tahunnya, sekitar $2,5 \%$ atau 125.000 orang meninggal, dan sisanya cacat ringan hampir setiap hari, atau minimal rerata tiap hari ada seorang penduduk Indonesia, baik tua maupun muda meninggal dunia karena serangan stroke (PDPERSI, 2010). 
Jawa Barat termasuk salah satu provinsi yang prevalensi penyakit strokenya di atas prevalensi nasional (Badan Penelitian dan Pengembangan Kesehatan, 2008). Kasus stroke di RSUD Kota Tasikmalaya dari tahun ke tahun jumlahnya terus meningkat dan menempati urutan pertama di antara seluruh kasus sistem persarafan di RSUD Kota Tasikmalaya. Sementara itu kasus stroke di RSUD Kabupaten Ciamis pun selalu menempati urutan pertama dari seluruh kasus sistem persyarafan yang ada (Rekam Medik RSUD Kota Tasikmalaya, 2010; Rekam Medik RSUD Kabupaten Ciamis, 2010).

Stroke merupakan salah satu penyakit yang menyebabkan kerusakan/kecacatan permanen, dan merupakan penyebab utama morbiditas dan mortalitas. Hasil statistik memperkirakan bahwa $29 \%$ klien stroke akan meninggal dalam waktu satu tahun, dengan $20 \%$ diantaranya meninggal dalam waktu tiga bulan, $25 \%$ mengalami ketergantungan, dan hanya $46 \%$ sisanya yang bisa hidup mandiri (American Heart Association, 2010).

Hemiparese merupakan masalah umum yang dialami oleh klien stroke. Hemiparese pada ekstremitas atas dapat menyebabkan klien mengalami berbagai keterbatasan, sehingga klien banyak mengalami ketergantungan dalam beraktivitas. Ketergantungan ini akan berlanjut sampai klien pulang dari RS, oleh karena itu, diperlukan manajemen yang baik agar kondisi hemiparese yang dialami oleh klien dapat teratasi dan klien dapat beraktivitas mandiri pasca stroke nanti.

Salah satu intervensi yang bisa dilakukan untuk mengatasi masalah hemiparese pada ekstremitas atas pasien stroke adalah dengan melakukan latihan range of motion (ROM) baik aktif maupun pasif. Penelitian oleh Lynch, et al. (2005) menyimpulkan bahwa latihan ROM dapat meningkatkan fleksibilitas sendi. Begitu juga penelitian Astrid (2008) mendapatkan hasil bahwa kekuatan otot meningkat dan kemampuan fungsional meningkat secara signifikan setelah diberikan latihan.
Selama ini latihan ROM lebih berfokus hanya pada bagian tubuh yang mengalami kelemahan (unilateral), sedangkan untuk sisi tubuh yang sehat tidak dilakukan latihan ROM secara terprogram. Terdapat satu pendekatan lain yang bisa diterapkan pada latihan ROM yang diprediksi dapat meningkatkan kekuatan otot pasien yaitu latihan yang ditujukan pada kedua sisi tubuh (latihan bilateral). Latihan bilateral pada tangan yang dilakukan pada klien paska stroke yang mengalami keterbatasan dalam menggunakan ekstremitas atas masih menimbulkan kesepakatan yang berbeda. Penelitian Stoykov dan Corcos, 2009 menunjukkan bahwa latihan bilateral pada tangan untuk klien dengan stroke moderat memberikan hasil yang lebih efektif pada kemampuan fungsional tangan klien stroke dibandingkan dengan latihan unilateral jika diukur dengan motor assesment scale. Sementara itu Lewis dan Byblow (2004) dalam penelitianya terhadap pasien pasca stroke (1-6 bulan) menyimpulkan bahwa latihan bilateral belum memberikan efek yang signifikan terhadap kemampuan motorik ekstremitas atas klien stroke.

Berdasarkan fenomena tersebut penelitian dengan memfokuskan pada latihan ROM untuk pasien stroke yang mengalami hemiparese perlu dilakukan. Penelitian ini membandingkan latihan ROM unilateral dan bilateral untuk mengetahui latihan yang memberikan efek yang lebih baik terhadap kemajuan fungsi motorik pada ekstremitas atas pasien dan dapat dijadikan acuan intervensi selanjutnya. Rumusan masalah dalam penelitian ini adalah "bagaimana perbandingan latihan ROM unilateral dan latihan ROM bilateral terhadap kekuatan otot ekstremitas pada pasien hemiparese akibat stroke iskemik?"

\section{Metode}

Penelitian ini menggunakan desain penelitian quasy experimental pre-post test design. Menggunakan dua kelompok intervensi (kelompok intervensi I dan kelompok intervensi II). Kelompok intervensi I diberikan intervensi latihan ROM unilateral, sedangkan kelompok intervensi II melakukan latihan ROM bilateral. 
Sampel sebanyak 30 penderita stroke diperoleh secara consecutive sampling di RSUD Kota Tasikmalaya dan RSUD Kabupaten Ciamis. Adapun kriteria inklusi antara lain, pasien dengan diagnosa medis stroke iskemik, mengalami hemiparese pada ekstremitas atas kanan atau kiri, memiliki kekuatan otot antara 1-3, pasien baru masuk dan belum mendapat terapi rehabilitasi di ruangan, dan bersedia menjadi responden. Kriteria ekslusinya yaitu, pasien dengan tanda vital tidak stabil, pasien mengalami penurunan kesadaran, dan pasien yang mengalami trauma atau injuri pada ekstremitas atas. Sampel dibagi dua, 15 orang kelompok intervensi I dan 15 orang kelompok intervensi II. Analisis statistik yang dipergunakan yaitu univariat dan bivariat dengan uji $t$ dependen dan $t$ independen serta analisis multivariat menggunakan uji Ancova.

\section{Hasil}

Rerata umur responden kelompok intervensi I adalah 60,73 tahun, sedangkan kelompok intervensi II 58,80 tahun. Sebagian besar kelompok intervensi I berjenis kelamin perempuan $(60 \%)$ sedangkan kelompok intervensi II adalah lakilaki $(73,30 \%)$. Kedua kelompok sebagian besar datang dengan serangan stroke pertama $(86,70 \%)$. Kelompok intervensi I sebagian besar mengalami hemiparese pada tangan kiri $(73,30 \%)$ sedangkan kelompok intervensi II sebagian besar mengalami hemiparese pada tangan kanan (60\%). Berdasarkan admission time, sebagian besar responden pada kelompok intervensi I maupun intervensi II datang ke rumah sakit kurang dari 6 jam $(66,70 \%)$.

Sebelum dilakukan analisis bivariat dilakukan uji normalitas yang merupakan syarat untuk uji $\mathrm{t}$ dependen dan independen. Hasil uji normalitas menunjukkan bahwa variabel usia terdistribusi normal dengan nilai 1,39; kekuatan otot sebelum latihan terdistribusi normal dengan nilai Skewness/ SE 0,00; begitu pula variabel kekuatan otot sebelum latihan terdistribusi normal dengan nilai Skewness/SE 0,94. Karena semua data terdistribusi dengan normal, maka analisis bivariat yang digunakan dalam penelitian ini adalah uji $\mathrm{t}$ dependen dan independen.
Sebelum dilakukan uji t independen, dilakukan uji homogenitas/uji kesetaraan untuk membandingkan kesetaraan karakteristik kelompok responden yang diuji. Hasilnya menunjukkan tidak ada perbedaan umur dan kekuatan otot yang signifikan antara kelompok intervensi I dan intervensi II untuk variabel usia dan kekuatan otot sebelum latihan $(p=0,625 ; \alpha=0,05)$. Tabel 1 menunjukkan rerata kekuatan otot sebelum intervensi pada kelompok intervensi I yaitu 1,93, rerata kekuatan otot sesudah intervensi yaitu 3,13. Hasil ini menunjukkan bahwa latihan ROM unilateral meningkatkan kekuatan otot sebesar 2,20. Hasil uji statistik disimpulkan terdapat perbedaan yang signifikan antara nilai kekuatan otot sebelum dan kekuatan otot sesudah latihan pada kelompok intervensi I $(\mathrm{p}=$ $0,001 ; \alpha=0,05)$.

Rerata kekuatan otot sebelum intervensi pada kelompok intervensi II yaitu 2,07 sedangkan rerata kekuatan otot sesudah intervensi yaitu 4,20. Hasil ini menunjukkan bahwa latihan ROM bilateral meningkatkan kekuatan otot sebesar 2,13. Hasil uji statistik menunjukkan ada perbedaan yang signifikan antara nilai kekuatan otot sebelum dan kekuatan otot sesudah latihan pada kelompok intervensi II $(p=0,001 ; \alpha=0,05)$.

Tabel 2 menunjukkan rerata kekuatan otot sesudah dilakukan latihan pada kelompok intervensi I adalah 3.13, sedangkan rerata kekuatan otot sesudah dilakukan latihan pada kelompok intervensi II adalah 4.20. Hasil ini menunjukkan bahwa rerata kekuatan otot pada kelompok yang diberi latihan ROM bilateral lebih tinggi daripada kelompok yang telah diberi latihan ROM unilateral.

Hasil uji statistik menunjukkan ada perbedaan yang siginifikan rerata kekuatan otot sesudah latihan pada kedua kelompok $(\mathrm{p}=0,018 ; \alpha=$ $0,05)$. Perbedaan perubahan atau kenaikan kekuatan otot diantara kedua kelompok dapat dilihat pada Tabel 2. Analisis multivariat dengan menggunakan uji Ancova model Type III Sum of Squares. Hasil analisis digambarkan sebagaimana pada Tabel 4. 
Tabel 3 menunjukkan bahwa kekuatan otot setelah dikontrol oleh variabel perancu terdapat hubungan yang signifikan antara latihan ROM dengan kekuatan otot pasien $(\mathrm{p}=$ $0,038 ; \alpha=0,05)$. Variabel usia, jenis kelamin, frekuensi serangan, sisi hemiparese, dan admission time tidak memiliki hubungan yang signifikan terhadap kekuatan otot responden ( $>0,5 ; \alpha=0,05$ ). Perbedaan rerata kekuatan otot sesudah latihan sebelum dan sesudah dikontrol variabel perancu digambarkan pada Tabel 5.

Tabel 1. Perbedaan Rerata Kekuatan Otot Sebelum dan Sesudah Intervensi

\begin{tabular}{ccccccc}
\hline Kelompok & Latihan ROM & Mean & SD & Beda Mean & p & N \\
\hline Intervensi I & Sebelum & 1,93 & 0,96 & 2,20 & 0,001 & 15 \\
& Sesudah & 3,13 & 1,25 & & & \\
Intervensi II & Sebelum & 2,07 & 0,88 & 2,13 & 0,001 & 15
\end{tabular}

*bermakna pada $\alpha=0,05$

Tabel 2. Distribusi Perbedaan Rerata Kekuatan Otot Sesudah Intervensi antara Kelompok Intervensi I \& II

\begin{tabular}{cccccc}
\hline Kelompok & Mean & SD & Beda mean & p & N \\
\hline Intervensi I & 3,13 & 1,25 & 1,07 & 0,018 & 15 \\
Intervensi II & 4,20 & 1,08 & & & 15 \\
\hline
\end{tabular}

Tabel 3. Distribusi Perbandingan Perubahan Rerata Kekuatan Otot Sebelum dan Sesudah Intervensi pada Kelompok Intervensi I \& II

\begin{tabular}{ccccc}
\hline Kelompok & Mean Sebelum & Mean Sesudah & Perubahan & Makna \\
\hline Intervensi I & 1,93 & 3,13 & Meningkat 1,20 & Kekuatan otot meningkat \\
Intervensi II & 2,07 & 4,20 & Meningkat 2,13 & Kekuatan otot meningkat \\
\hline
\end{tabular}

Tabel 4. Hasil Analisis Ancova Pengaruh Latihan ROM terhadap Kekuatan Otot

\begin{tabular}{lcc}
\hline Source & B & Sig. \\
\hline Correction Model & 3,622 & 0,040 \\
Usia & 0,034 & 0,134 \\
Jenis kelamin & $-0,387$ & 0,456 \\
Frekuensi serangan & $-0,151$ & 0,821 \\
Sisi hemiparese & $-0,752$ & 0,113 \\
Admission time & 0,170 & 0,720 \\
Jenis latihan & $-1,060$ & 0,038 \\
\hline
\end{tabular}

Tabel 5. Perbedaan Rerata Kekuatan Otot Setelah Latihan Sebelum dan Sesudah Dikontrol Variabel Confounding

\begin{tabular}{lccc}
\hline \multicolumn{1}{c}{ Kelompok } & $\mathbf{n}$ & $\begin{array}{c}\text { Mean sebelum dikontrol } \\
\text { variabel confounding }\end{array}$ & $\begin{array}{c}\text { Mean sesudah dikontrol variabel } \\
\text { confounding }\end{array}$ \\
\hline Intervensi I & 15 & 3,13 & 3,137 \\
Intervensi II & 15 & 4,20 & 4,20 \\
\hline
\end{tabular}


Berdasarkan Tabel 5 dapat dilihat bahwa tidak ada perbedaan yang berarti pada nilai rerata kekuatan otot setelah latihan pada kedua kelompok sebelum dan sesudah dikontrol variabel perancu. Hal ini menunjukkan ada peningkatan kekuatan otot setelah intervensi merupakan hasil dari intervensi yang dilakukan dan bukan merupakan pengaruh dari variabel perancu yang ada. Jadi secara umum hasil penelitian menunjukkan nilai rerata kekuatan otot pada kelompok intervensi I meningkat sebesar 1,20 sedangkan pada kelompok intervensi II meningkat sebesar 2,13.

\section{Pembahasan}

Hemiparese (kelemahan) atau hemiplegia (kelumpuhan) pada sebagian sisi tubuh dapat terjadi setelah serangan stroke. Kelainan ini biasanya disebabkan karena kerusakan pembuluh darah bagian anterior atau arteri serebral medial yang mengakibatkan infark pada korteks motorik frontalis. Hemiplegia komplit melibatkan sebagian wajah, lidah, dan ekstremitas atas dan bawah pada sisi tubuh yang sama. Infark pada bagian sisi kanan otak akan mengakibatkan kelumpuhan pada bagian sisi kiri tubuh karena jaras serabut saraf akan menyilang pada traktus pyramidal yang melewati otak sampai medulla spinalis.

Hasil penelitian menunjukkan bahwa pada kedua kelompok intervensi terdapat penurunan kekuatan otot. Hal ini sesuai dengan konsep yang ada yang menyatakan bahwa pasien stroke dapat mengalami hemiparese, yang salah satunya ditandai oleh menurunnya kemampuan motorik pasien stroke yang dapat diidentifikasi dari menurunnya kekuatan otot pasien. Setelah dilakukan intervensi berupa latihan ROM menunjukkan terdapatnya peningkatan kekuatan otot pada kedua kelompok intervensi. Latihan ROM secara signifikan dapat meningkatkan kekuatan otot pasien selama dilakukan dengan teknik yang tepat. Latihan dilakukan secara terprogram minimal dua kali/hari (Berman, Snyder, Kozier, \& Erb, 2008; Potter \& Perry, 2006)
Hasil analisis lebih lanjut menunjukkan bahwa, baik latihan ROM unilateral maupun latihan ROM bilateral dapat meningkatkan kekuatan otot pasien dengan hemiparese. Latihan ROM merupakan salah satu bentuk latihan dalam proses rehabilitasi yang dinilai masih cukup efektif untuk mencegah terjadinya kecacatan pada pasien dengan stroke. Secara konsep, latihan ROM dikatakan dapat mencegah terjadinya penurunan fleksibilitas sendi dan kekakuan sendi (Lewis, Dirksen, Heitkemper, \& Bucher, 2007).

Terdapat banyak artikel yang membahas tentang efek latihan ROM dengan capaian yang bervariasi dan populasi yang beragam pula, diantaranya Lynch, et al. (2005) menyimpulkan bahwa latihan ROM dapat meningkatkan fleksibilitas sendi. Berbagai penelitian tersebut menunjukkan bahwa latihan ROM memberikan manfaat yang baik bagi klien termasuk pada klien stroke. Ini sejalan dengan apa yang dihasilkan penelitian ini. Setelah mendapatkan latihan ROM baik unilateral maupun bilateral, didapatkan kenaikan yang signifikan pada kekuatan otot pasien. Latihan ROM dapat menggerakkan persendian seoptimal dan seluas mungkin sesuai kemampuan seseorang dan tidak menimbulkan rasa nyeri pada sendi yang digerakkan.

Secara konsep, latihan tangan dengan menggunakan pendekatan bilateral akan memberikan hasil yang lebih baik dibandingkan dengan pendekatan unilateral. Hal ini disebabkan karena latihan bilateral melibatkan dua sisi hemisfer otak, sehingga pada saat latihan dilakukan terjadi aktivasi pada kedua sisi hemisfer otak. Latihan yang menggunakan pendekatan unilateral menyebabkan inhibisi pada gerakan lengan kontra lateral, sehingga latihan unilateral ini hanya mengaktivasi satu bagian dari otak. Latihan bilateral memberikan efek yang lebih baik karena kedua hemisfer tetap aktif dan kekuatan motorik kedua tangan dapat tetap baik (Waller \& Whitall, 2005).

Latihan ROM dengan menggunakan pendekatan bilateral bisa meningkatkan kekuatan otot pasien lebih baik dibandingkan dengan latihan ROM 
unilateral. Hal ini tentu saja sejalan dengan konsep latihan fungsional tangan secara keseluruhan, yaitu bahwa konsep bilateral dapat mengaktivasi kedua sisi hemisfer otak. Latihan ROM yang dilakukan dengan pendekatan bilateral dapat memberikan keuntungan yang lebih baik, karena pada saat latihan ROM bilateral ini dilakukan, terjadi aktivasi pada kedua sisi hemisfer otak yang dapat membantu pemulihan kekuatan motorik pasien stroke dengan lebih baik.

Hasil penelitian ini sejalan dengan beberapa penelitian tentang Bilateral Arm Training yang sudah dilakukan. Penelitian Stoykov dan Corcos (2009) menunjukkan bahwa latihan bilateral pada tangan untuk klien dengan stroke moderat memberikan hasil efektif meningkatkan kemampuan fungsional tangan klien stroke dibandingkan dengan unilateral jika diukur dengan motor assesment scale. Salah satu hasil yang didapat dalam penelitian Stoykov \& Corcos (2009) dengan motor assesment scale adalah meningkatnya kemampuan fungsi ekstremitas atas yang salah satunya adalah kekuatan otot pasien.

Waller \& Whitall (2005), selain itu, menyimpulkan bahwa latihan bilateral dapat meningkatkan lengan yang mengalami parese lebih baik dibandingkan dengan latihan unilateral, hanya saja dalam pelaksanaannya memerlukan pendekatan yang lebih spsesifik disesuaikan dengan karakteristik dasar dari pasien stroke. Selain itu dinyatakan pula bahwa latihan bilateral dalam peningkatan kemampuan fungsi tangan secara keseluruhan dalam pemenuhan kebutuhan sehari-hari dengan lebih baik dibandingkan latihan unilateral. Pendapat ini sejalan pula dengan penelitian yang dilakukan oleh Chang, et al. (2006) yang menyatakan bahwa latihan bilateral pada tangan dianggap sebagai suatu strategi penatalaksanaan hemiparese, dan dapat dimasukan dalam tindakan rehabilitasi stroke yang memberikan dampak yang lebih besar dalam memfasilitasi pergerakan aktif pada tangan dan meningkatkan kinerja motor kontrol pada tangan yang mengalami parese.
Namun demikian ada beberapa penelitian yang tidak sejalan dengan apa yang peneliti dapatkan tentang latihan ROM bilateral. Penelitian ini tidak menunjukkan hasil yang baik tentang latihan bilateral. Desrosiers, et al. (2005), melakukan suatu randomized controlled trial untuk membuktikan perbandingan efektifitas latihan lengan unilateral dan bilateral pada pasien stroke dengan fase subakut. Penelitian ini membuktikan bahwa baik latihan lengan unilateral maupun bilateral tidak mengurangi kecacatan atau memperbaiki fungsional klien stroke lebih dari terapi biasa.

\section{Kesimpulan}

Rerata nilai kekuatan otot meningkat sesudah diberikan latihan ROM, baik pada kelompok intervensi I maupun kelompok intervensi II, hal ini menunjukan bahwa latihan ROM baik unilateral maupun bilateral berpengaruh terhadap peningkatan kekuatan otot pasien stroke.

Terdapat perbedaan peningkatan kekuatan otot antara responden yang melakukan latihan ROM unilateral dan latihan ROM bilateral, dari hasil penelitian didapatkan bahwa latihan ROM bilateral meningkatkan kekuatan otot lebih baik dibandingkan dengan latihan ROM unilateral. Hasil penelitian menunjukkan nilai rerata kekuatan otot pada kelompok intervensi I meningkat sebesar 1,20 sedangkan pada kelompok intervensi II meningkat sebesar 2,13. Tidak terdapat kontribusi faktor perancu: usia, jenis kelamin, sisi hemiparese, frekuensi serangan, dan admission time pada pengaruh latihan ROM terhadap kekuatan otot ekstremitas atas pasien hemiparese akibat stroke.

Latihan ROM bilateral perlu dilakukan secara terprogram di setiap institusi pelayanan keperawatan oleh perawat dengan bekerja sama dengan keluarga setelah terlebih dahulu diajarkan tentang latihan ROM. Untuk penelitian lebih lanjut perlu dilakukan di lingkup keperawatan medikal bedah, baik di institusi pelayanan maupun pendidikan, dengan melakukan penelitian pada jenis stroke hemoragik dengan waktu 
penelitian yang lebih lama sesuai dengan waktu pemulihan pasien stroke hemoragik, misalnya selama dua minggu. Perlu juga dilakukan penelitian pada pasien pasca stroke dalam fase sub akut, misalnya untuk pasien yang sudah berada di rumah dengan melakukan latihan bilateral pada tangan dengan capaian kemampuan fungsional pasien pasca stroke. Kemampuan fungsional tersebut bisa diukur dengan menggunakan Barthel Indeks atau Katz indeks $(\mathrm{JH}$, $\mathrm{RS}, \mathrm{KN}$ ).

\section{Referensi}

American Heart Association. (2010). Heart diseases and stroke statistic: Our guide to current statistics and the supplement to our heart and stroke fact-2010 update. Diperoleh dari http://www.americanheart.org.

Astrid. (2008). Pengaruh latihan range of motion (ROM) terhadap kekuatan otot, luas gerak sendi dan kemampuan fungsional pasien stroke di RS Sint Carolus Jakarta (Tesis, Tidak dipublikasikan). Fakultas Ilmu Keperawatan Universitas Indonesia, Jakarta.

Badan Penelitian dan Pengembangan Kesehatan. (2008). Laporan nasional riskesda 2007, Badan Penelitian dan Pengembangan Kesehatan Departemen Kesehatan, Republik Indonesia. Diakses dari: http://www.litbang. depkes.go.id.

Berman, A., Snyder, S., Kozier, B., \& Erb, G. (2008). Kozier and Erb's Fundamentals of nursing, concept, process and practice (8th Ed.). New Jersey: Pearson Education.

Chang, J.J., Tung, W. L., Wu, W.L., \& Su, F.C. (2006). Effect of bilateral reaching on affected arm motor control in stroke with and without loading on unaffected arm. Disability \& Rehabilitation, 28(24), 1507-1516.

Desrosiers, J., Bourbonnais, D., Corriveau, H., Gosselin, S., \& Bravo, G. (2005). Effectiveness of unilateral and symme- trical bilateral task training for arm during the subacute phase after stroke: A randomized controlled trial. Clinical Rehabilitation, 19(6), 581-593.

Lewis, G.N., \& Byblow, W.D. (2004). Neurophysiological and behavioural adaptations to a bilateral training intervention in individuals following stroke. Clinical Rehabilitation, 18 (1), 48-59.

Lewis, S.L., Dirksen, S.R., Heitkemper, M.M., \& Bucher, L. (2007). Medical surgical nursing: Assessment \& management of clinical problem (7th Ed.). St.Louis: Mosby-Year Book, Inc.

Lynch, D., Ferraro, M., Krol, J., Trudell, C.M., Christos, P., \& Volpe, B.T. (2005). Continuous passive motion improves shoulder joint integrity following stroke. Clinical Rehabilitation, 19 (6), 594-599.

Waller, S.M., \& Whitall, J. (2005). Hand dominance and side of stroke affect rehabilitation in chronic stroke. Clinical Rehabilitation, 19 (5), 544-551.

PDPERSI. (2010). Stroke, penyebab utama kecacatan fisik. http://pdpersi.co.id.

Potter, A.P., \& Perry, A. (2006). Fundamental of nursing (4th Ed.). St.Louis: Mosby-Year Book, Inc.

Rekam Medis RSUD Kabupaten Ciamis. (2010). Laporan kasus rawat inap dan rawat jalan RSUD Kabupaten Ciamis. Ciamis: RSUD Kabupaten Ciamis.

Rekam Medis RSUD Kota Tasikmalaya. (2010). Laporan kasus rawat inap dan rawat jalan RSUD Kota Tasikmalaya. Tasikmalaya: RSUD Kota Tasikmalaya.

Stoykov, M. E., \& Corcos, D. M. (2009). A review of bilateral training for upper extremity hemiparesis. Occupational Therapy International, 16 (3-4), 190-203. 